\title{
Simulation of Rainfall Runoff Process Using HEC-HMS Model for Upper Godavari Basin Maharashtra, India
}

\author{
Vaishnavi K. Patil, Vidya R. Saraf, Omkesh V. Karad, Swapnil B. Ghodke, Dnyaneshwar K. Gore, \\ Shweta S. Dhekale
}

\begin{abstract}
To simulate rainfall- runoff process popularly used watershed model is Hydrologic Engineering Centers Hydrologic Modeling System (HEC-HMS), which is generally used to estimate the basin's hydrological phenomenon caused due to precipitation. It helps to predict the various hydrologic responses to watershed management and to have a best understanding of the effect of these practices. It is specific from the spacious study of the literature that the studies on relative assessment for hydrologic simulations are finite in developing countries including India. In this study, modified SCS Curve Number method is applied to determine loss model as a major component in rainfall-runoff modeling. The study of HECHMS model is used to simulate rainfall-runoff process in Nasik region (Upper Godavari basin), Maharashtra. To enumerate runoff volume, peak runoff rate, and flow routing methods SCS curve number, SCS unit hydrograph, Exponential recession and Muskingum routing methods are chosen, respectively. The results of the present study indicate that HEC-HMS tool applied to watershed proved to be useful in achieving the various objectives. The study confirmed a sensible increase in runoff as a result of urbanization.
\end{abstract}

Index Terms-HEC-HMS, Rainfall, Runoff, SCSCN.

\section{INTRODUCTION}

WATER is scarce and there are millions of people across this globe who spend their entire day searching for it; so there is primary need to save water. Collection and calculation of runoff is one of the remedy to save water; there are various Hydrological models are available for calculation of runoff but HEC -HMS is a choice of suitable one which is important of accurate prediction. The hydrologic modeling system is designed to simulate intact hydrologic processes of watershed systems. It incorporates much traditional hydrologic analysis. In that case, evapotranspiration, infiltration, percolation, and other

\footnotetext{
Published on April 22, 2019.

V. K. Patil is the Student of civil Engineering Department Government College of Engineering, Jalgaon, India. E-mail: vaishnavip2912@gmail.com.

V. R. Saraf is the Assistant Professor of Department of civil Engineering Government College of Engineering, Jalgaon, India. E-mail: vrsaraf@yahoo.com.

O. V. Karad is the Student of Civil Engineering Department Government College of Engineering, Jalgaon, India. E-mail: omkeshkarad@gmail.com.

S. B. Ghodke is the Student of Civil Engineering Department Government College of Engineering, Jalgaon, India. E-mail: ghodkeswapnil1@gmail.com.

D. K. Gore is the Student of Civil Engineering Department Government College of Engineering, Jalgaon, India. E-mail: gored80@ gmail.com

S. S. Dhekale is the Student of Civil Engineering Department Government College of Engineering, Jalgaon, India. E-mail: dhekaleshweta100@gmail.com.
}

locomotion and storage should be tracked over a long time and detailed accounting model is required. This model computes and reports the peak volume or the hydrograph of watershed runoff. The components which will predict runoff are represented in detail and the other components are omitted. For example, in a common application, HEC-HMS omits any detailed accounting of movement of water vertically within the soil layer. Infiltration, unit hydrographs and hydrographic routing. It encloses procedures necessary for continuous simulation including evapo-transpiration, snow melt and soil moisture accounting. Forward capabilities are also provided for gridded runoff simulation using the linear cursory-distributed runoff transform. Supplemental analysis tools are provided for parameter estimation, depth area analysis, flow forecasting, erosion and sediment transport and nutrient water quality.

The programme features is integrated work environment with a database, data entry utilities, computation and results reporting tools. A graphical user interface allows the user seamless movement between the different part of the program. Simulation results are stored in the data storage system HEC-HEC-DSS and can be used as amalgamation with other software for studies of water availability, drainage, flow forecasting, future urbanization, and reservoir

Hydrological modeling is a commonly used tool to estimate the basin's hydrological response due to precipitation. It allows to predict the hydrologic response to various watershed management practices and to have a better understanding of the impacts of these practices. It is evident from the extensive review of the literature that the studies on comparative assessment of watershed models for hydrologic simulations are very much limited in developing countries including India. There is bare necessity to undertake study on hydrologic simulation through development of a suitable watershed model. The Hydrologic Engineering Centers Hydrologic Modeling System (HECHMS) is a popularly used watershed model to simulate rainfall- runoff process.

\section{OBJECTIVES}

The overall objective of study project can be formulated as follows:

1) To use HEC-HMS for simulation of stream flow of the river.

2) To complete hydrologic processes of watershed system.

3) To assess the change in runoff with response to urbanization within a basin in Nasik region (Godavari watershed) using HEC-HMS. Submission. 


\section{METHODOLOGY}

Methodology of study project given by flowchart which shows the step of workflow as follows

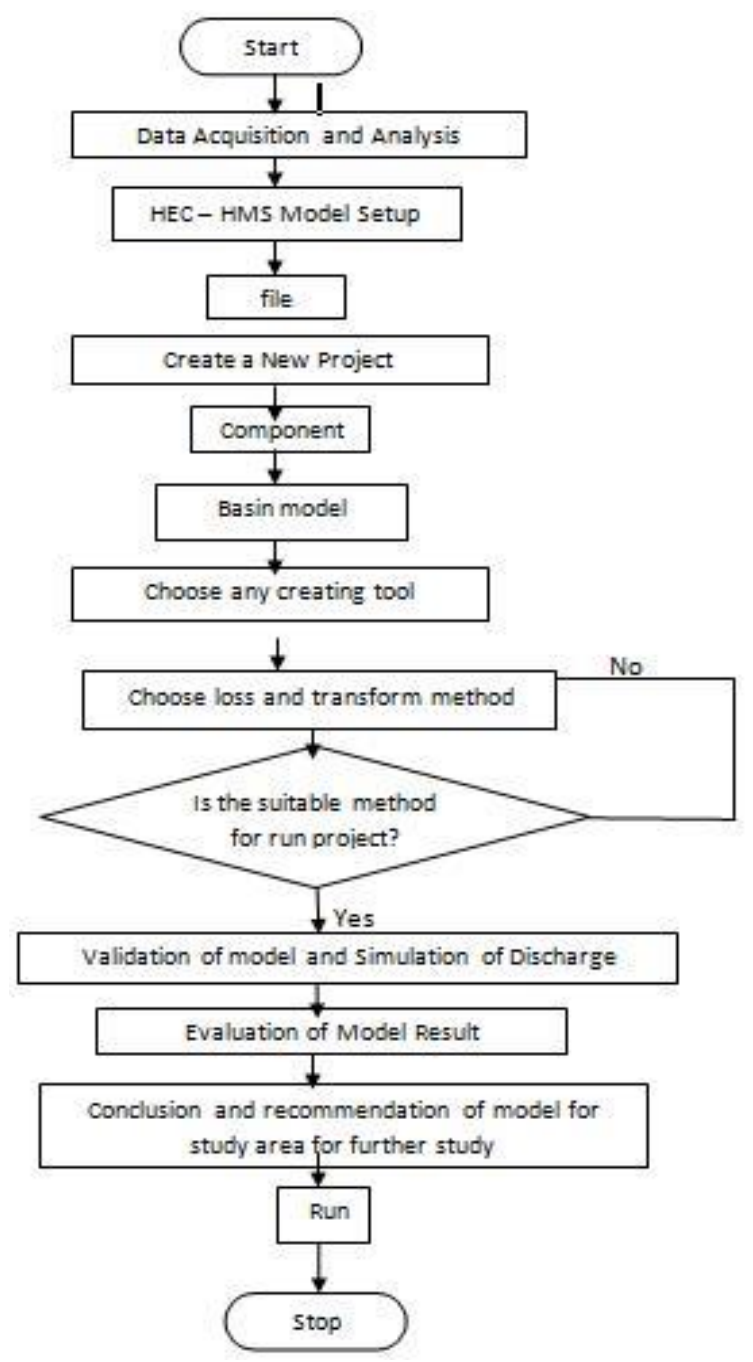

Fig. 1. Methodology of study

\section{A. Study Area}

The study area is located in Nasik region of Maharashtra. The water shade includes Nasardi, Godavari and Darna river. The salient features of watershed are given below:

\section{1) Location and accessibility:}

The study area falls in western part of Maharashtra. The area of watershed is about 300sq.km. The watershed lies between $19{ }^{\circ} 59^{\prime} 50^{\prime}$ " N latitude and $73^{\circ} 47^{\prime} 23.29$ ” E. It is located at an altitude of $583 \mathrm{~m}$ above MSL. The watershed area is delineated from Google earth as shown in Fig. 2.

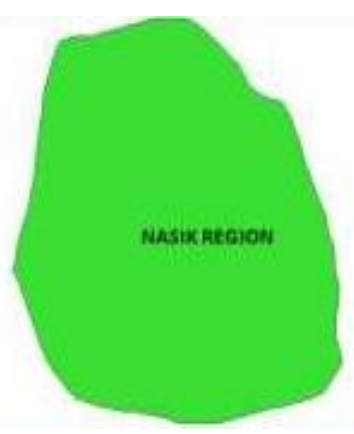

Fig. 2. Study area
Method used for this study area is Soil Conservation System Curve Number (SCS-CN) Method as Follows: The SCS Curve number method is simple, widely used and efficient method for determining the approximated amount of runoff from a rainfall even in a particular area. Although the method is designed for a single storm, it can be scaled to find average annual runoff values. HEC-HMS provides various methods to calculate the loss rate in the basin/subbasin such as Deficit and constant, exponential loss, GreenAmpt, SCS Curve Number, initial and Constant. Among the methods, the SCS-CN method is widely used. For effective rainfall calculation soil conservation service curve number is used. The method estimates precipitation excess as function of cumulative, soil cover, land use and antecedent moisture. the $\mathrm{CN}$ values are estimated on the basis of soil respectively.

In this study, modified SCS Curve Number method is applied to determine loss model as a major component in rainfall-runoff modeling. The objective of this study is to specify the results of SCS-CN loss model to estimate runoff in Nasik region watershed on long time daily rainfall data. The $\mathrm{CN}$ are based on hydrologic soil groups

Group $\boldsymbol{A}$ is sand, loamy sand or sandy loam types of soils. It has low runoff potential and high infiltration rates even when thoroughly wetted. They consist chiefly of deep, well to excessively drained sands or gravels and have a high rate of water transmission.

Group $\boldsymbol{B}$ is silt loam or loam. It has a moderate infiltration rate when thoroughly wetted and consists chiefly or moderately deep to deep, moderately well to well drained soils with moderately fine to moderately coarse textures.

Group $\boldsymbol{C}$ soils are sandy clay loam. They have low infiltration rates when thoroughly wetted and consist chiefly of soils with a layer that impedes downward movement of water and soils with moderately fine to fine structure.

Group $D$ soils are clay loam, silty clay loam, sandy clay, silty clay or clay. This HSG has the highest runoff potential. They have very low infiltration rates when thoroughly wetted and consist chiefly of clay soils with a high swelling potential, soils with a permanent high water table, soils with a clay pan or clay layer at or near the surface and shallow soils over nearly impervious material Soil Conservation System Curve Number used for studyArea is as follows:

In central Nashik region the soil available is moderately deep, moderately well drained, fine, moderately calcareous soil on gently sloping undulating lands with moderate erosion. This type of soil comes under group B, having SCS curve number 74. In surrounding area of Nashik region, the soil available are very shallow, well drained, clayey soils on moderately sloping undulating lands with severe erosion. This type of soil comes under group D, having SCS curve number 86

\section{B. Data Used}

The data entered in the software was collected from various sources are given in Table I. 
TABLE I: DATA TYPE AND DATA SOURCES

\begin{tabular}{cc}
\hline \hline Data type & Data Source \\
\hline Drainage & Topographic maps \\
\hline Contour & DEM-topographic \\
\hline DEM (Digital Elevation Model) & maps \\
\hline Soil & SRTM \\
\hline Geomorphology and land use & IRS P4 Resourcesat \\
\hline Rainfall data (1Jan2001 to 31july2014) & Global \\
\hline \hline
\end{tabular}

C. Calculation of lag time

1) Time of concentration:

$$
T_{C} \frac{100 L^{0.8}\left(\frac{1000}{C N}-9\right)^{0.7}}{1900 S^{0.5}}
$$

where,

$\mathrm{CN}=\mathrm{SCS}$ runoff curve number

$\mathrm{S}=$ Average watershed slope in $\%$

\section{2) Lag time:}

$\mathrm{TL}=0.6 \times \mathrm{T}_{\mathrm{c}}$

where $T_{c}=$ time of concentration (in hour)

\section{3) Sample Calculation:}

1) Time of concentration for Godavari basin Length of Godavari basin $=81342$ feet

$$
\begin{aligned}
& \text { Tc }=\frac{100 \times 81342^{0.8}\left(\frac{1000}{74}-9\right)^{0.7}}{1900 \times(78972.81)^{0.5}} \\
& \text { Tc }=3.12 \mathrm{hr} .=3.12 \times 60=187.2 \mathrm{~min} . \\
& \mathrm{TL}=0.6 \times \mathrm{Tc} \\
& =0.6 \times 187.2 \\
& \mathrm{TL}=112.32 \mathrm{~min} .
\end{aligned}
$$

\section{RESULTS AND DISCUSSION}

The data was collected for the Nasik region for determining the impact on runoff due to urbanization analysis of the proposed future urbanization show that there has been significant change in peak discharge of the discharges different element of the watershed as shown in Table II

TABLE II: PARAMETER OF EXISTING BASIN

\begin{tabular}{llll}
\hline \hline River & Peak discharge & $\begin{array}{l}\text { Precipitation } \\
\text { volume }(\text { cu.mm) }\end{array}$ & $\begin{array}{l}\text { Direct } \\
\text { runoff }\end{array}$ \\
\hline Nasardi & 217.8 & 22755914.2 & 2269862.5 \\
Darna & 155.6 & 1625653 & 1621330.4 \\
Godavari & 404.5 & 4226697.8 & 4215458.9 \\
Substream 1 & 71.6 & 747800.4 & 745698.0 \\
Substream 2 & 84 & 877852.6 & 875384 \\
\hline \hline
\end{tabular}

\section{A. For Godavari Basin}

Fig. 3. shows the graph for direct runoff which is plotted between year and flow. peak runoff is obtained in 2012 is $250 \mathrm{~mm}$ average minimum runoff is obtained in 2003 is $90 \mathrm{~mm}$.

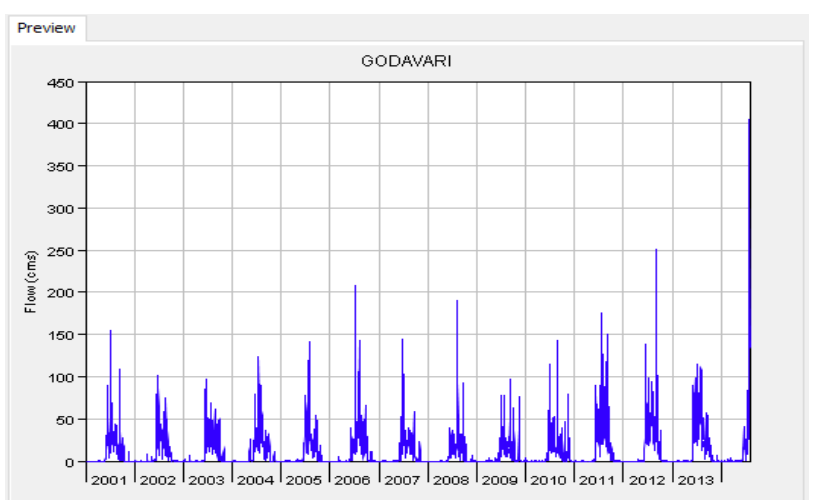

Fig. 3. Graph for Direct Runoff of Godavari

Fig. 4 shows the graph for precipitation which is plotted between year and depth $(\mathrm{mm})$. Average peak precipitation is obtained in the year 2012 is $220 \mathrm{~mm}$ and average minimum precipitation is obtained in the year 2003 is $70 \mathrm{~mm}$.

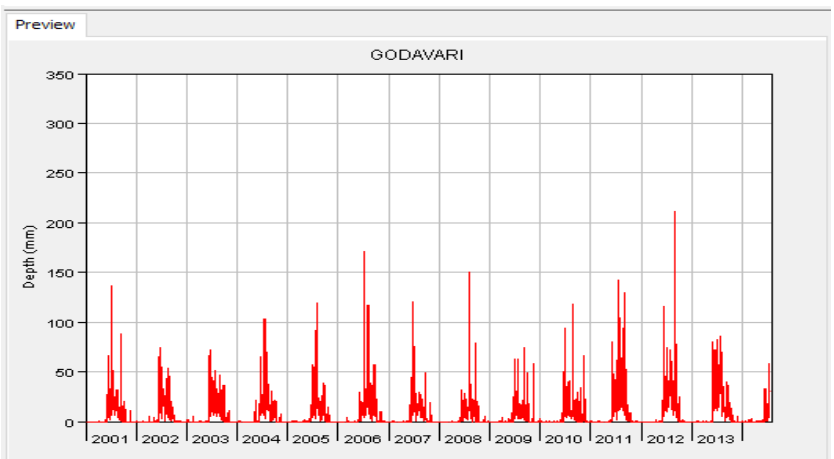

Fig. 4. Graph for Precipitation of Godavari

\section{B. For Nasardi Basin}

Fig. 5 shows the graph for direct runoff which is plotted between year and flow. Peak runoff is obtained in 2012 is $140 \mathrm{~mm}$ average minimum runoff is obtained in 2003 is $55 \mathrm{~mm}$.

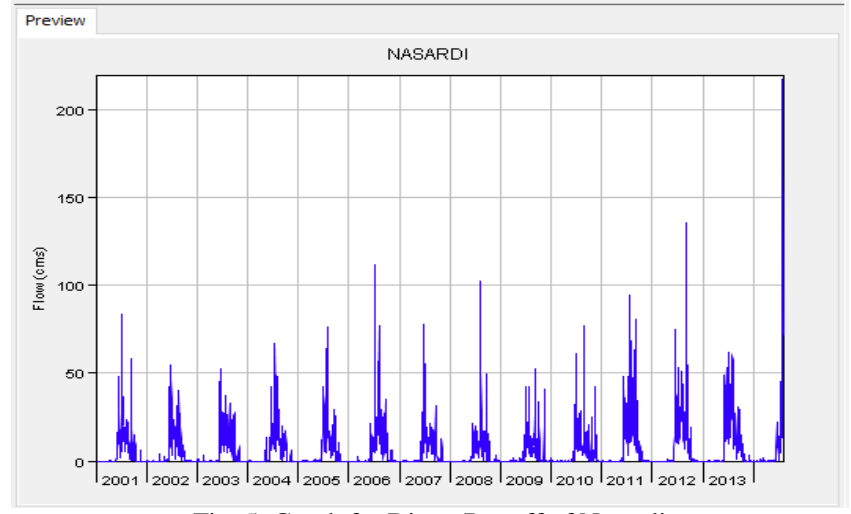

Fig. 5. Graph for Direct Runoff of Nasardi

Fig. 6 shows the graph for precipitation which is plotted between year and depth $(\mathrm{mm})$. Average peak precipitation is obtained in the year 2012 is $220 \mathrm{~mm}$ and average minimum precipitation is obtained in the year 2003 is $70 \mathrm{~mm}$ 


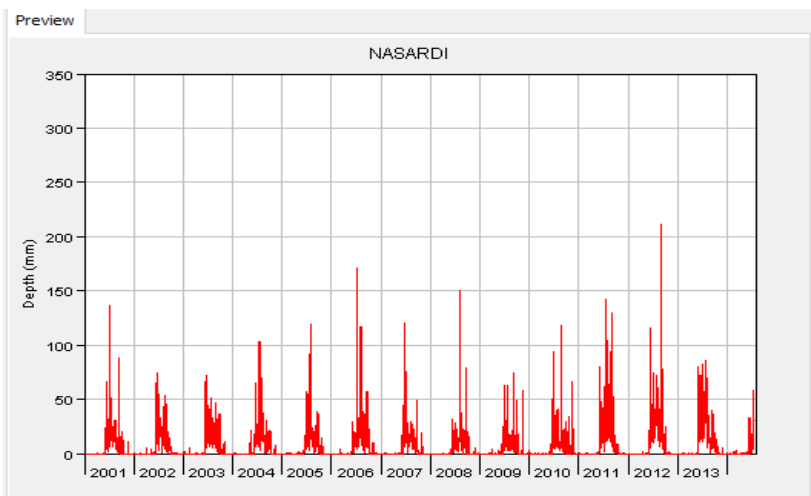

Fig. 6. Graph for Precipitation of Nasardi

\section{For Darna Basin}

Fig. 7 shows the graph for direct runoff which is plotted between year and flow. peak runoff is obtained in 2012 is $95 \mathrm{~mm}$ average minimum runoff is obtained in 2003 is $45 \mathrm{~mm}$

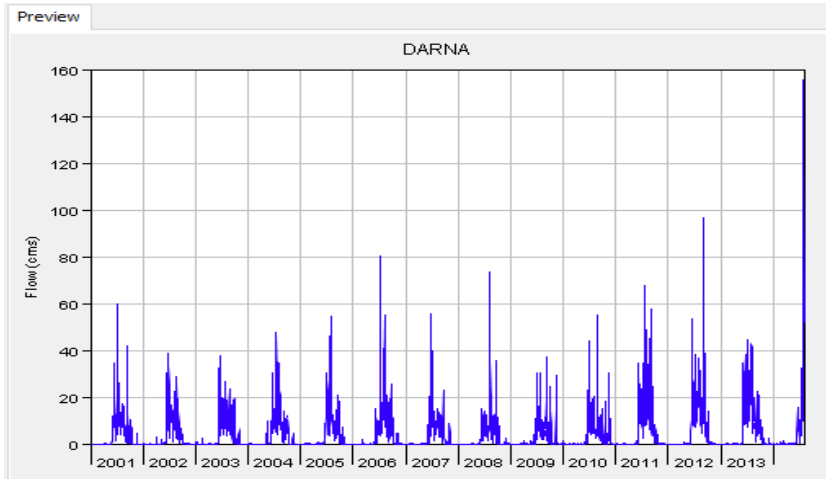

Fig. 7. Graph for Direct Runoff of Darna

Fig. 8 shows the graph for precipitation which is plotted between year and depth $(\mathrm{mm})$. average peak precipitation is obtained in the year 2012 is $220 \mathrm{~mm}$ and average minimum precipitation is obtained in the year 2003 is $70 \mathrm{~mm}$.

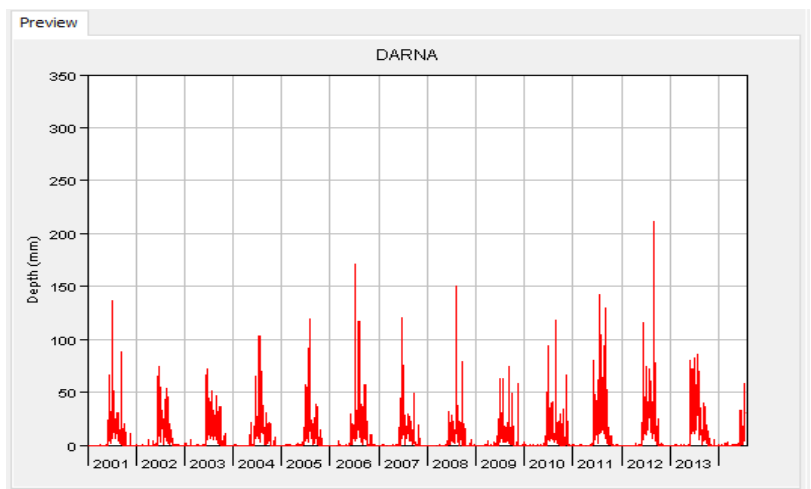

Fig. 8. Graph for Precipitation of Darna

\section{For Substream 1}

Fig. 9 shows the graph for direct runoff which is plotted between year and flow. peak runoff is obtained in 2012 is $45 \mathrm{~mm}$ average minimum runoff is obtained in 2003 is $18 \mathrm{~mm}$

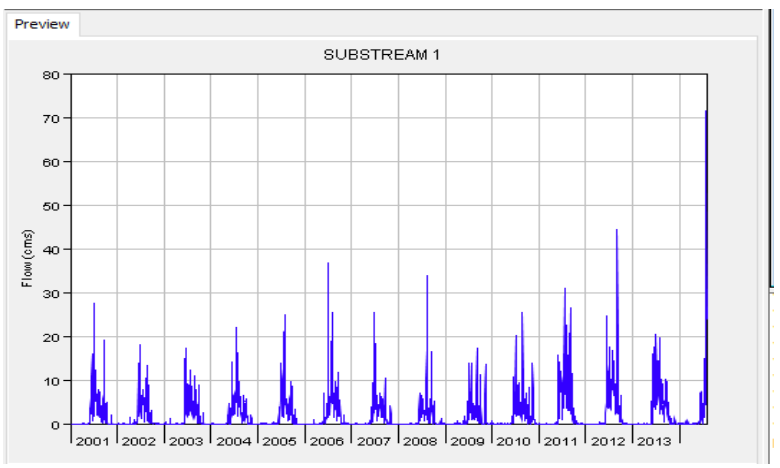

Fig. 9. Graph for Direct Runoff of Substream 1

Fig. 10 shows the graph for precipitation which is plotted between year and depth ( $\mathrm{mm})$. average peak precipitation is obtained in the year 2012 is $220 \mathrm{~mm}$ and average minimum precipitation is obtained in the year 2003 is $70 \mathrm{~mm}$

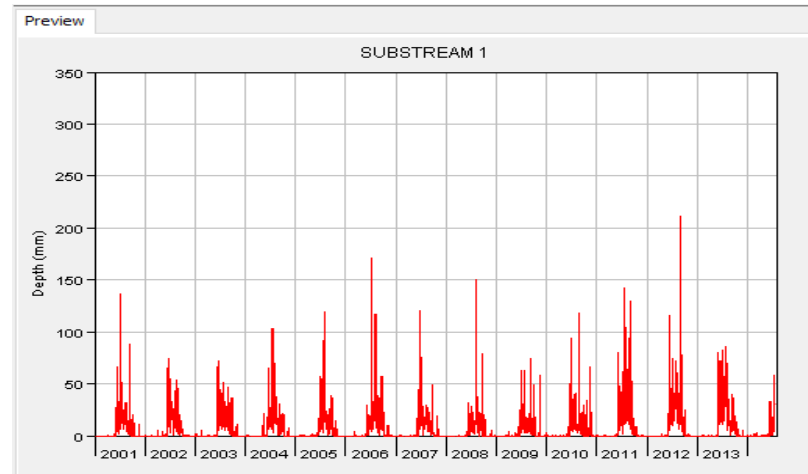

Fig. 10. Graph for precipitation of Substream 1

\section{E. For Substream 2}

Fig. 11 shows the graph for direct runoff which is plotted between year and flow. peak runoff is obtained in 2012 is 53 $\mathrm{mm}$ average minimum runoff is obtained in 2003 is $20 \mathrm{~mm}$.

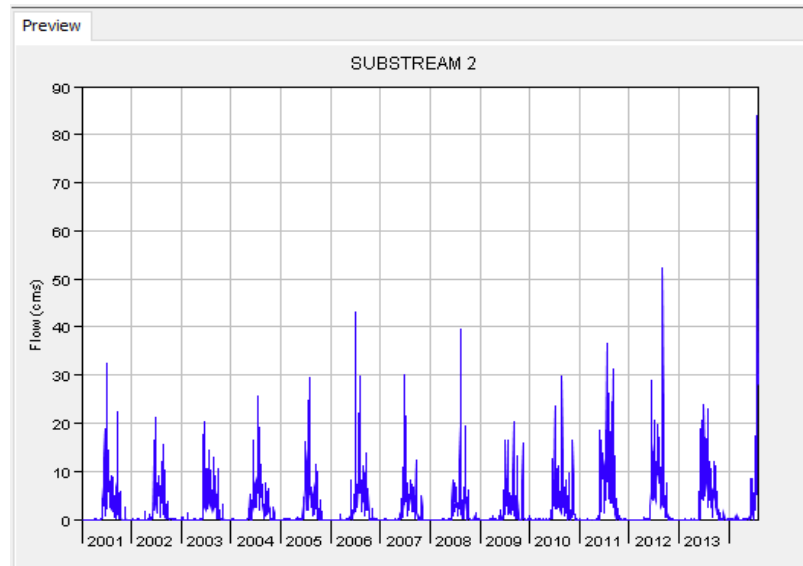

Fig. 11. Graph for Direct Runoff of Susstream 2

Fig. 12 shows the graph for precipitation which is plotted between year and depth $(\mathrm{mm})$ average peak precipitation is obtained in the year 2012 is $220 \mathrm{~mm}$ and average minimum precipitation is obtained in the year 2003 is $70 \mathrm{~mm}$. 


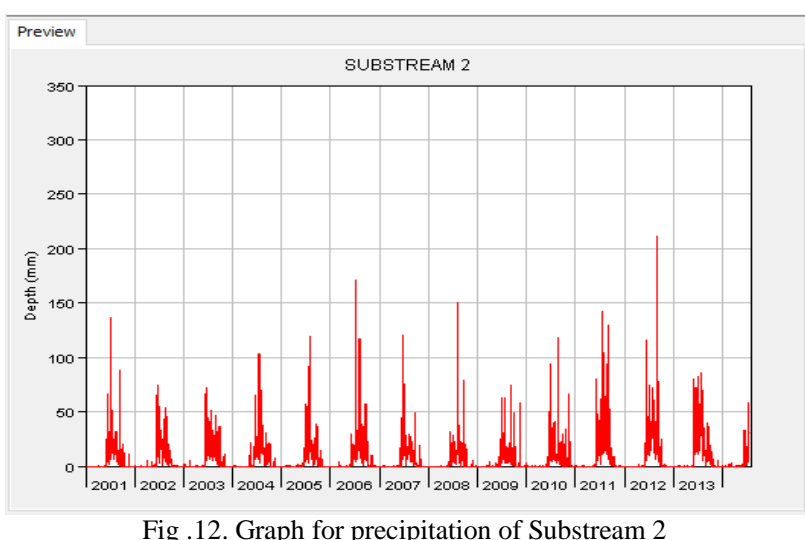

Fig .12. Graph for precipitation of Substream 2

Table III shows the time series results for Godavari basin at daily interval to control simulation. The time series table includes the same information as the graph shown below but in numerical format. shows year at which storm has been occurred and shows the average time interval which has been specified in control specification. represents the average precipitation occurred at each interval. Interception, infiltration, storage, evaporation and transpiration collectively are referred as losses in HEC-HMS program. Also the average excess rainfall in a given duration obtained by subtracting average losses from total rainfall. Average of direct runoff of excess precipitation on a watershed shown Base flow is taken as 0 in this model which is shows the average total flow.

Table IV. shows the time series results for Nasardi basin at daily interval to control simulation start and stop. The time series table gives information in numerical format shows year at which storm has been occurred and shows the average time interval which has been specified in control specification. It represents the average precipitation occurred at each interval. Interception, infiltration, storage, evaporation and transpiration collectively are referred as losses in HEC-HMS program also it shows the average excess rainfall in a given duration obtained by subtracting average losses from total rainfall. Average of direct runoff of excess precipitation on a watershed. Base flow is taken as 0 which is shown as average total flow.

Table $\mathrm{V}$ shows the time series results for Darna basin at daily interval to control simulation. The time series table includes the same information as the graph shown below but in numerical format. shows year at which storm has been occurred and the average time interval which has been specified in control specification. Also represents the average precipitation occurred at each interval. Interception, infiltration, storage, evaporation and transpiration collectively are referred as losses in HEC-HMS program it shows the average excess rainfall in a given duration obtained by subtracting average losses from total rainfall. Average of direct runoff of excess precipitation on a watershed and Base flow is taken as 0 in this model which is shown in the average total flow.

Table VI shows the time series results for Substream 1 basin at daily interval to control simulation. The time series table gives information in numerical format. shows year at which storm has been occurred and the average time interval which has been specified in control specification. Also represents the average precipitation occurred at each interval. Interception, infiltration, storage, evaporation and transpiration collectively are referred as losses in HEC-HMS program which are shown the average excess rainfall in agiven duration obtained by subtracting average losses from total rainfall. Average of direct runoff of excess precipitation on a watershed. Base flow is taken as 0 in this model which is shows the average total flow.

Table VII shows the time series results for Substream 2 basin at daily interval to control simulation. The time series table gives information in numerical format. It shows year at which storm has been occurred and the average time interval which has been specified in control specification. Also represents the average precipitation occurred at each interval. Interception, infiltration, storage, evaporation and transpiration collectively are referred as losses in HEC-HMS program and the average excess rainfall in a given duration obtained by subtracting average losses from total rainfall. Average of direct runoff of excess precipitation on a watershed. Base flow is taken as 0 in this model which is shown in the average total flow.

TABLE III: TIME SERIES RESULTS FOR GODAVARI BASIN

\begin{tabular}{ccccc}
\hline \hline $\begin{array}{c}\text { Row } \\
\text { Labels }\end{array}$ & $\begin{array}{c}\text { Average } \\
\text { of ppt } \\
(\mathrm{MM})\end{array}$ & $\begin{array}{c}\text { Average } \\
\text { of loss } \\
(\mathrm{MM})\end{array}$ & $\begin{array}{c}\text { Average of } \\
\text { exces } \\
(\mathrm{MM})\end{array}$ & $\begin{array}{c}\text { Average of total } \\
\text { flow (M3/s) }\end{array}$ \\
\hline 2001 & 5.84 & 0.046 & 5.797 & 8.6986 \\
2002 & 5.45 & 0.00013 & 5.45 & 8.2109 \\
2003 & 6.36 & 0 & 6.36 & 9.5701 \\
2004 & 6.36 & 0 & 6.364 & 9.572 \\
2005 & 5.65 & 0 & 5.652 & 8.5043 \\
2006 & 6.84 & 0 & 6.8417 & 10.294 \\
2007 & 5.06 & 0 & 5.064 & 7.6205 \\
2008 & 4.97 & 0 & 4.9792 & 7.491 \\
2009 & 4.44 & 0 & 4.4435 & 6.686 \\
2010 & 5.91 & 0 & 5.917 & 8.9008 \\
2011 & 10.23 & 0 & 10.23 & 15.40 \\
2012 & 8.92 & 0 & 8.919 & 13.46 \\
2013 & 9.01 & 0 & 9.0145 & 13.56 \\
2014 & 6.78 & 0 & 6.7807 & 10.028 \\
Grand & 6.56 & 0.0034 & 6.552 & 9.8499 \\
Total & & & & \\
\hline \hline
\end{tabular}

TABLE IV: TIME SERIES RESULTS FOR NASARDI BASIN

\begin{tabular}{ccccc}
\hline \hline $\begin{array}{c}\text { Row } \\
\text { Labels }\end{array}$ & $\begin{array}{c}\text { Average of } \\
\text { ppt } \\
(\mathrm{MM})\end{array}$ & $\begin{array}{c}\text { Average of } \\
\text { loss } \\
(\mathrm{MM})\end{array}$ & $\begin{array}{c}\text { Average of } \\
\text { exces } \\
(\mathrm{MM})\end{array}$ & $\begin{array}{c}\text { Average of } \\
\text { direct flow } \\
(\mathrm{M} 3 / \mathrm{s})\end{array}$ \\
\hline 2001 & 5.844 & 0.099478 & 4.642192 & 4.6422 \\
2002 & 5.45 & 0.001452 & 4.419178 & 4.4192 \\
2003 & 6.36041 & 0.000192 & 5.153151 & 5.1532 \\
2004 & 6.3641 & $2.73 \mathrm{E}-05$ & 5.155464 & 5.1555 \\
2005 & 5.6529 & 0 & 4.581644 & 4.5816 \\
2006 & 6.84172 & 0 & 5.541096 & 5.5411 \\
2007 & 5.0648 & 0 & 4.103562 & 4.1036 \\
2008 & 4.97927 & 0 & 4.034153 & 4.0342 \\
2009 & 4.4435 & 0 & 3.597534 & 3.5975 \\
2010 & 5.91706 & 0 & 4.792055 & 4.7921 \\
2011 & 10.235 & 0 & 8.295068 & 8.2951 \\
2012 & 8.9199 & 0 & 7.225956 & 7.226 \\
2013 & 9.01452 & 0 & 7.303014 & 7.303 \\
2014 & 6.7807 & 0 & 5.397642 & 5.3976 \\
Grand & 6.5569 & 0.007425 & 5.300161 & 5.3002 \\
Total & & & & \\
\hline \hline
\end{tabular}


TABLE V: TIME SERIES RESULTS FOR DARNA BASIN

\begin{tabular}{ccccc}
\hline \hline $\begin{array}{c}\text { Row } \\
\text { Labels }\end{array}$ & $\begin{array}{c}\text { Average of } \\
\text { ppt } \\
(\mathrm{MM})\end{array}$ & $\begin{array}{c}\text { Average of } \\
\text { loss } \\
(\mathrm{MM}))\end{array}$ & $\begin{array}{c}\text { Average of } \\
\text { exces } \\
(\mathrm{MM})\end{array}$ & $\begin{array}{c}\text { Average of } \\
\text { direct flow } \\
(\mathrm{M} 3 / \mathrm{s})\end{array}$ \\
\hline 2001 & 5.8441 & 0.0994 & 5.7446 & 4.6421917 \\
2002 & 5.458 & 0.0014 & 5.4573 & 4.4191780 \\
2003 & 6.360 & 0.000191 & 6.3602 & 5.1531506 \\
2004 & 6.36 & 2.732 & 6.364 & 5.1554644 \\
2005 & 5.65 & 0 & 5.652 & 4.5816438 \\
2006 & 6.841 & 0 & 6.84 & 5.5410958 \\
2007 & 5.0648 & 0 & 5.0648 & 4.1035616 \\
2008 & 4.97 & 0 & 4.979 & 4.0341530 \\
2009 & 4.443 & 0 & 4.443 & 3.5975342 \\
2010 & 5.9170 & 0 & 5.9170 & 4.7920547 \\
2011 & 10.237 & 0 & 10.2 & 8.2950684 \\
2012 & 8.91 & 0 & 8.9199 & 7.2259562 \\
2013 & 9.0145 & 0 & 9.014 & 7.3030136 \\
2014 & 6.780 & 0 & 6.78 & 5.3976415 \\
Grand & 6.556 & 0.007424 & 6.54 & 5.3001612 \\
Total & & & & \\
\hline \hline
\end{tabular}

TABLE VI: TIME SERIES RESULTS FOR SUBSTREAM 1 BASIN

\begin{tabular}{ccclc}
\hline \hline $\begin{array}{c}\text { Row } \\
\text { Labels }\end{array}$ & $\begin{array}{c}\text { Average } \\
\text { of ppt }\end{array}$ & $\begin{array}{c}\text { Average of } \\
\text { loss }\end{array}$ & $\begin{array}{c}\text { Average } \\
\text { of } \\
\text { excess }\end{array}$ & Average of total flow \\
\hline 2001 & 5.844 & 0.060164835 & 5.797 & 1.535342466 \\
2002 & 5.45 & 0.000191781 & 5.45 & 1.452876712 \\
2003 & 6.36041 & 0 & 6.36 & 1.692876712 \\
2004 & 6.3641 & 0 & 6.364 & 1.692622951 \\
2005 & 5.6529 & 0 & 5.652 & 1.503013699 \\
2006 & 6.84172 & 0 & 6.8417 & 1.823835616 \\
2007 & 5.0648 & 0 & 5.064 & 1.348219178 \\
2008 & 4.97927 & 0 & 4.9792 & 1.324590164 \\
2009 & 4.4435 & 0 & 4.4435 & 1.181643836 \\
2010 & 5.91706 & 0 & 5.917 & 1.575616438 \\
2011 & 10.235 & 0 & 10.23 & 2.724657534 \\
2012 & 8.9199 & 0 & 8.919 & 2.374043716 \\
2013 & 9.01452 & 0 & 9.0145 & 2.400273973 \\
2014 & 6.7807 & 0 & 6.7807 & 1.771698113 \\
Grand & 6.5569 & 0.004430329 & 6.552 & 1.742096774 \\
Total & & & & \\
\hline \hline
\end{tabular}

TABLE VII: TIME SERIES RESULTS FOR NASARDI BASIN

\begin{tabular}{ccclc}
\hline \hline $\begin{array}{l}\text { Row } \\
\text { Labels }\end{array}$ & $\begin{array}{c}\text { Average of } \\
\text { ppt } \\
(\mathrm{MM})\end{array}$ & $\begin{array}{c}\text { Average of } \\
\text { loss } \\
(\mathrm{MM})\end{array}$ & $\begin{array}{c}\text { Average of } \\
\text { exces } \\
(\mathrm{MM})\end{array}$ & $\begin{array}{c}\text { Average of total } \\
\text { flow } \\
(\mathrm{M} 3 / \mathrm{s})\end{array}$ \\
\hline 2001 & 5.844 & 0.06016484 & 5.797 & 1.802191781 \\
2002 & 5.45 & 0.00019178 & 5.45 & 1.703835616 \\
2003 & 6.36041 & 0 & 6.36 & 1.984931507 \\
2004 & 6.3641 & 0 & 6.364 & 1.987704918 \\
2005 & 5.6529 & 0 & 5.652 & 1.765753425 \\
2006 & 6.84172 & 0 & 6.8417 & 2.136164384 \\
2007 & 5.0648 & 0 & 5.064 & 1.58109589 \\
2008 & 4.97927 & 0 & 4.9792 & 1.556010929 \\
2009 & 4.4435 & 0 & 4.4435 & 1.386849315 \\
2010 & 5.91706 & 0 & 5.917 & 1.846849315 \\
2011 & 10.235 & 0 & 10.23 & 3.197260274 \\
2012 & 8.9199 & 0 & 8.919 & 2.786885246 \\
2013 & 9.01452 & 0 & 9.0145 & 2.816438356 \\
2014 & 6.7807 & 0 & 6.7807 & 2.082075472 \\
Grand & 6.5569 & 0.00443033 & 6.552 & 2.04419354 \\
Total & & & & \\
\hline \hline
\end{tabular}

\section{CONCLUSION}

The goal of this study is to identify whether the development of an open area in the watershed of Nasik region increases the runoff and if so, how much. Results of the present study indicate that HEC-HMS tool applied to watershed in Nasik region (Godavari basin), Maharashtra proves to be useful in achieving the various objectives as discussed below:

1. The simulation results indicate that the increase in urbanization and change in land use has increased the peak runoff significantly.

2. This study is done on a small watershed so the change in peak runoff due to urbanization is limited but if the same study is carried out for bigger watersheds, it will provide significant results like identifying solutions to current and future flooding, including controls on land use.

3. If the development is to be permitted, then impact of future development can be predicted and existing flood impacts can be characterized.

\section{REFERENCES}

[1] Anderson M. L., Z. Q. Chen, Kavvas M. L, Arlen Feldman "Coupling HEC-HMS with Atmospheric Models for Prediction of Watershed Runoff”' Journal of Hydrologic Engineering, Vol. 7, No. 4, Pp. 312318, July1, Year 2013.

[2] Chunale G. L., Gorantiwar S. D and Satpute G. U. "Event Based Rainfall- Runoff Simulation Using HEC-HMS Model for Small Agricultural Watershed" National Conference on Sustainable Water Resources development and Management (SWARDAM), 2013

[3] De Silva M. M. G. T, Weerakoon S. B. and Herath Srikantha "Modeling of Event and Continuous Flow Hydrographs with HECHMS: Case Study in the Kelani River Basin, Sri Lanka" Journal of Hydrologic Engineering, Vol. 19, No. 4, Pp800-806 April 1, 2014

[4] Gandhi H. M., Dr. Shrimali N. J. and Patel M. M. "Literature Study On Application of HEC-HMS for Event and Continuous Based Hydrological Modeling" Vol 1, issue 11, Pp 2489-2491, 2014

[5] Kumar D. and Bhattacharya R."Distributed rainfall runoff modeling" International Journal of Earth Sciences and Engineering, Vol 4, issue 6, Pp 270-75,2011.

[6] Mokhtari Fahimeh, Soltani Saeid, and Seyed Alireza Mousavi "Assessment of Flood Damage on Humans, Infrastructure, and Agriculture in the Ghamsar Watershed Using HEC-FIA Software" Nat. Hazards Rev., Pp1527-6988, 2017

[7] Paul Jagadish Chandra, Choudhary Kishor and Panigrahi Balram "Simulation of rainfall-runoff process using HEC-HMS model for Balijore Nala watershed, Odisha, India" International Journal of Geomatics and Geosciences Volume 5 Issue 2, 2014

[8] Putty M. R. Y., Prasad R "Understanding Runoff Processes using a watershed model a case study in the Western Ghats in South India" Vol 228, issue 3-4, Pp 215-227, 13 March 2000.

[9] Watkins W David., Gyawali Rabi, "Continuous Hydrologic Modeling of Snow Affected Watersheds in The Great Lakes Basin Using HECHMS" Journal of Hydrologic Engineering, Vol.18

[10] Yener M.K. "Semi-Distributed Hydrologic Modelling Studies in Yuvacik Basin", International Congress on River Basin Management, Vol 634, September, 2006.

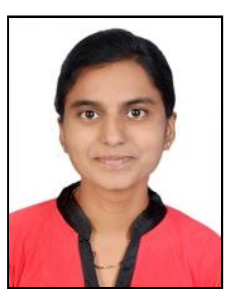

\section{Miss Vaishnavi Kiran Patil}

Date of Birth: 29 December 1996

Qualification: B.Tech (Civil ) from Government College of Engineering, Jalgaon 